\title{
Distribution of Microorganisms in Spices and Their Decontamination by Gamma-irradiation
}

\author{
Muhamad Lebai Juri,* Hitoshi Ito, Hiroshi Watanabe \\ and Naoyuki TAmura \\ Takasaki Radiation Chemistry Research Establishment, \\ Japan Atomic Energy Research Institute, \\ Takasaki 370-12, Japan
}

Received June 4, 1985

\begin{abstract}
The distribution of microorganisms in 15 samples of selected spices and the effects of irradiation of them were studied. The total aerobic bacteria in black pepper, white pepper, turmeric, rosemary and basil were determined to be $3 \times 10^{3}$ to $5 \times 10^{7}$ per gram. Coliforms were also determined in 8 samples to be $2 \times 10^{2}$ to $2 \times 10^{6}$ per gram. The main aerobic-spore-formers were identified as Bacillus pumilus and B. subtilis. Molds were determined in 10 samples to be $1 \times 10^{2}$ to $2 \times 10^{4}$ per gram which consisted mainly of the Aspergillus glaucus, A. restrictus, A. flavus, $A$. fumigatus, $A$. niger groups and Penicillium. A study on the inactivation of microorganisms in spices showed that gamma-irradiation doses of 1.2 to $1.5 \mathrm{Mrad}$ were required to reduce the total aerobic bacteria to below a detectable level, while doses of below 1.0 Mrad were required to decrease the spore-forming bacteria to below $10^{3}$ per gram, the Japanese hygenic standard. Coliforms were eliminated with 0.4 to $1.0 \mathrm{Mrad}$ irradiation. In the storage study, at humidity levels higher than $84 \%$ at 30 or $35^{\circ} \mathrm{C}$, mold counts increased more than $10^{6}$ per gram in many kinds of powdered spices in polyethylene pouches during 1 to 2 months of storage, while samples subjected to $0.4 \mathrm{Mrad}$ irradiation were free from molds.
\end{abstract}

The frequent contamination by microorganisms of imported spices has been causing serious problems for the food industry in Japan. The contamination of spices may occur during harvesting, handling, transportation and storage in the exporting countries. ${ }^{1,2)}$ Processed spices with a high bio-burden utilized in the food industry accelerate the putrefaction of manufactured food products. Mold growth under unfavorable conditions during long storage and shipment should also cause quality changes and occasionally mycotoxin production. In many countries, both fumigation with ethylene oxide and heat sterilization have been tried with varying degrees of success. However, these methods have several disadvantages for application to the sterilization of spices such as toxic residues are left and organoleptic properties are changed. $^{3,4)}$ For these reasons, the spice traders are required to seek alternative methods for decontamination. There have been many reports that radiation treatment is a suitable method for decontaminating spices, ${ }^{3 \sim 7)}$ and commercial scale use of radiation processing for spices has been successful in several European countries and the U.S.A. ${ }^{8)}$ in recent years. However, there have been only a few reports on the decontamination effect on spices of irradiation under Japanese conditions. A survey of 26 kinds of imported spices reported previously showed that more than $50 \%$ of the species showed levels of more than $10^{4}$ spore-forming bacteria per gram, and gamma-irradiation doses of 0.5 to $1.5 \mathrm{Mrad}$ were required to decrease the spore-forming bacteria to below a detectable level. ${ }^{9)}$ This report presents data on the distribution of microorganisms in, the efficacy of gamma-irradiation for decontamination of,

\footnotetext{
* Present address: Nuclear Energy Unit, Prime Minister Department, Bangi, Selangor, Malaysia.
} 
and storage effects on many spices available in Japan.

\section{MATERIALS AND METHODS}

1. Materials. Nine kinds of spices were obtained from local companies in Japan. All of the 19 samples of these spices were imported from several countries.

2. Enumeration of the microbial load. The total aerobic bacteria were determined by the surface plate agar method with medium containing Difco-nutrient agar $23 \mathrm{~g}$, glucose $5 \mathrm{~g}$, yeast extract $5 \mathrm{~g}$, and $\mathrm{K}_{2} \mathrm{HPO}_{4} 2 \mathrm{~g}$ per liter ( $\mathrm{pH}$ 7.2). Coliforms were counted on Difco-MacConkey agar. Fungi were counted on MYG-chloramphenicol agar containing malt extract $10 \mathrm{~g}$, yeast extract $4 \mathrm{~g}$, glucose $4 \mathrm{~g}$, agar $20 \mathrm{~g}$, and chloramphenicol $20 \mathrm{mg}$ per liter (pH 6.0). Osmophilic molds were counted on $15 \% \mathrm{NaCl}$-malt agar containing malt extract $50 \mathrm{~g}, \mathrm{NaCl} 150 \mathrm{~g}$, and agar $20 \mathrm{~g}$ per liter $(\mathrm{pH} 6.0)$.

Five $\mathrm{g}$ of each sample was added to $50 \mathrm{ml}$ of $0.01 \%$ Tween-20 sterile water and homogenized throughly in a plastic bag with a Coloworth stomacher Lab-Blender- 400 for one minute. Each suspension was diluted $10^{2}$ or $10^{4}$ times with the same sterile water, and then $0.2 \mathrm{ml}$ aliquots were spread on the surface of agar plates. For whole spices, the samples were ground in a blender under sterile conditions prior to mixing with sterile water. Total aerobic bacteria, fungi and osmophilic molds were counted after $3 \sim 7$ days incubation at $30^{\circ} \mathrm{C}$. Coliforms were counted after 16 to 18 hours incubation at $37^{\circ} \mathrm{C}$.

Detection of salmonellae in some selected spices having heavy coliform loads was also performed by the same method as that used for fish meal. ${ }^{10)}$

3. Microbiological identification. After enumeration of the microorganisms on the agar plates, representative strains of the total aerobic bacteria, coliforms, fungi and osmophilic molds were selected and transferred onto suitable agar slants. Identification to the levels of genus and species was performed with reference to "Bergey's Manual of Determinative Bacteriology"11) and "The Genus Aspergillus."12)

4. Gamma-irradiation. For irradiation, the spices. were packed, from 5 to $20 \mathrm{~g}$, into polyethylene pouches. The gamma-ray source used was the $100 \mathrm{kCi}$ cobalt-60 irradiator in this Institute. The dose rate at the irradiation position was 0.5 to $1.0 \mathrm{Mrad}$ per hour, as determined with a Fricke dosimeter.

5. Storage studies. Nine kinds of spices and one sample of fish meal were packed, $20 \mathrm{~g}$ each, into polyethylene pouches, and then stored after irradiation in a chamber kept at 30 or $35^{\circ} \mathrm{C}$ and a relative humidity of $78 \sim 98 \%$ for 28 to 56 days.

6. Estimation of aflatoxin producing ability. The conventional plate agar ${ }^{13)}$ containing $\left(\mathrm{NH}_{4}\right) \mathrm{H}_{2} \mathrm{PO}_{4} 10 \mathrm{~g}$, $\mathrm{MgSO}_{4} \cdot 7 \mathrm{H}_{2} \mathrm{O} 0.5 \mathrm{~g}, \mathrm{KCl} 0.5 \mathrm{~g}, \mathrm{FeSO}_{4} \cdot 7 \mathrm{H}_{2} \mathrm{O} 0.01 \mathrm{~g}$, sucrose $30 \mathrm{~g}, \mathrm{HgCl}_{2} 5 \times 10^{-4} \mathrm{M}$, corn steep liquor $0.5 \mathrm{~g}$, and agar $25 \mathrm{~g}$ per liter ( $\mathrm{pH} 5.5$ ) was used for estimation of aflatoxin production after incubating a large colony of the $A$. flavus group at $28^{\circ} \mathrm{C}$ for $7 \sim 10$ days. The chloroform extract from the surrounding zone of a large colony was assayed by thin-layer-chromatography with development with chloroform-acetone $(9: 1)$.

Table I. Distribution of Microorganisms in Spices (per gram)

\begin{tabular}{|c|c|c|c|c|c|}
\hline \multicolumn{2}{|l|}{ Type of spice } & \multirow{2}{*}{$\begin{array}{c}\text { Total bacteria } \\
5.3 \times 10^{7}\end{array}$} & \multirow{2}{*}{$\begin{array}{c}\text { Coliforms } \\
1.5 \times 10^{4}\end{array}$} & \multirow{2}{*}{$\begin{array}{c}\begin{array}{c}\text { Osmophilic } \\
\text { molds }\end{array} \\
6.5 \times 10^{4}\end{array}$} & \multirow{2}{*}{$\begin{array}{c}\text { Fungi } \\
5.5 \times 10^{3}\end{array}$} \\
\hline P. Black pepper & A & & & & \\
\hline P. Black pepper & $\mathrm{B}$ & $3.8 \times 10^{7}$ & $9.9 \times 10^{3}$ & $7.1 \times 10^{3}$ & $3.0 \times 10^{3}$ \\
\hline W. Black pepper & A & $2.0 \times 10^{7}$ & - & - & - \\
\hline W. Black pepper & $\mathrm{B}$ & $4.8 \times 10^{7}$ & $8.9 \times 10^{3}$ & $2.7 \times 10^{4}$ & $3.4 \times 10^{3}$ \\
\hline P. White pepper & A & $9.2 \times 10^{4}$ & $1.7 \times 10^{2}$ & $6.3 \times 10^{3}$ & $3.1 \times 10^{3}$ \\
\hline P. White pepper & $\mathrm{B}$ & - & - & - & - \\
\hline W. White pepper & A & $9.3 \times 10^{4}$ & - & $2.6 \times 10^{3}$ & $2.5 \times 10^{2}$ \\
\hline W. White pepper & B & $9.8 \times 10^{5}$ & $2.0 \times 10^{6}$ & $2.9 \times 10^{4}$ & $1.7 \times 10^{4}$ \\
\hline P. Turmeric & $\mathrm{A}$ & $3.6 \times 10^{7}$ & $5.7 \times 10^{2}$ & $2.6 \times 10^{3}$ & $8.1 \times 10^{3}$ \\
\hline P. Turmeric & B & $3.1 \times 10^{6}$ & $7.5 \times 10^{1}$ & - & - \\
\hline W. Turmeric & B & $6.7 \times 10^{5}$ & - & - & - \\
\hline P. Rosemary & A & $4.9 \times 10^{3}$ & - & $5.6 \times 10^{3}$ & $2.1 \times 10^{3}$ \\
\hline P. Rosemary & B & $2.2 \times 10^{6}$ & $5.8 \times 10^{2}$ & $7.5 \times 10^{1}$ & $1.5 \times 10^{2}$ \\
\hline W. Rosemary & B & $2.8 \times 10^{3}$ & - & - & - \\
\hline P. Basil & A & $9.0 \times 10^{6}$ & $9.0 \times 10^{2}$ & $2.8 \times 10^{2}$ & $6.5 \times 10^{2}$ \\
\hline
\end{tabular}

- , below the detectable limit; P, powder sample: W, whole sample; A, B, samples with different capital letters were obtained at different times. 
Table II. Some Characteristics of Typical Bacteria in Spices

\begin{tabular}{|c|c|c|c|c|c|c|c|c|c|c|}
\hline Species & Morphology & $\begin{array}{l}\text { Gram- } \\
\text { reaction }\end{array}$ & Motility & $\begin{array}{c}\text { Spore } \\
\text { formation }\end{array}$ & Oxidase & Glucose & $\begin{array}{c}\text { Starch } \\
\text { hydrolysis }\end{array}$ & $\begin{array}{c}\text { Nitrate } \\
\text { reduction }\end{array}$ & $\begin{array}{c}\text { Methyl } \\
\text { red }\end{array}$ & $\begin{array}{l}\text { No. of } \\
\text { isolates }\end{array}$ \\
\hline Bacillus subtilis & Rods & + & + & + & \pm & \multirow{2}{*}{$\begin{array}{l}\text { Oxidized } \\
\text { Oxidized \& } \\
\text { fermented }\end{array}$} & + & + & $*$ & 8 \\
\hline Bacillus licheniformis & Rods & + & + & + & \pm & & + & + & * & 1 \\
\hline Bacillus pumilus & Rods & + & + & + & + & Oxidized & - & - & $*$ & 4 \\
\hline Bacillus megaterium & Large rods & + & + & + & + & Oxidized & + & + & $*$ & 1 \\
\hline Micrococcus varians & Cocci & + & - & - & - & Oxidized & - & + & $*$ & 1 \\
\hline Pseudomonas radiora & Rods & - & + & - & + & Oxidized & \pm & + or - & $*$ & 2 \\
\hline Klebsiella sp. & Short rods & - & - & - & - & Fermented & $*$ & + & - & 13 \\
\hline Enterobacter sp. & Short rods & - & + & - & - & Fermented & $*$ & + & - & 12 \\
\hline Citrobacter sp. & Short rods & - & + & - & - & Fermented & $*$ & + & + & 4 \\
\hline
\end{tabular}

* Not tested. 


\section{RESULTS}

\section{Distribution of microorganisms in spices}

As shown in Table I, total aerobic bacteria in black pepper, white pepper, turmeric, rosemary and basil were determined to be $3 \times 10^{3}$ to $5 \times 10^{7}$ per gram, except for white pepper $\mathrm{B}$, in which no microorganisms were detected. The main aerobic bacteria were identified as Bacillus subtilis and B. pumilus, with lower frequencies of $B$. megaterium, B. licheniformis, Micrococcus and Pseudomonas radiora (Table II).

Coliforms were also determined in 8 samples to be $2 \times 10^{2}$ to $2 \times 10^{6}$ per gram. The coliforms species mainly consisted of Klebsiella, Enterobacter and Citrobacter. No pathogenic species such as Salmonella and Escherichia were detected.

Molds were determined in 10 samples to be $1 \times 10^{2}$ to $7 \times 10^{4}$ per gram, which consisted mainly of the Aspergillus glaucus, A. restrictus, $A$. flavus, $A$. fumigatus and $A$. niger groups, and Penicillium and Rhizopus, and lower frequencies of the $A$. ochraceus and $A$. wentii groups, as shown in TAble III. In this case, all of 11 isolates of the A. flavus group were identified as $A$. flavus var. columnaris, and 2 strains produced afratoxins that gave blue fluorescent spots on thin layer chromatography $\left(\mathrm{B}_{1}, \mathrm{~B}_{2}\right.$ etc. $)$ by the conventional plate agar method, as shown in Fig. 1.

\section{Inactivation of microorganisms in spices}

Three kinds of spices highly contaminated by microorganisms were used for the inactivation study with gamma-irradiation. Figures $2 \sim 4$ show the inactivation curves for microorganisms in turmeric, black pepper and white pepper. The estimated dose for eliminating the microorganisms to below a detectable level, especially the total aerobic bacteria, ranged from 1.2 to $1.5 \mathrm{Mrad}$. Coliforms in spices were eliminated with 0.4 to $1.0 \mathrm{Mrad}$. Generally, molds and coliforms required lower doses for inactivation compared to total bacteria because of the high frequency of Bacillus in the latter.

The $D_{10}$ values in $0.067 \mathrm{M}$ phosphate buffer under aerobic conditions of B. pumilus strains $\mathrm{S} 2, \mathrm{~S} 4$ and S30 ranged from $0.16 \sim 0.17 \mathrm{Mrad}$, and those for B. subtilis $\mathrm{S} 1, \mathrm{~S} 14$ and $\mathrm{S} 18$, and $B$. licheniformis $\mathrm{S} 34$ ranged from $0.13 \sim 0.14$ Mrad. That for B. megaterium S31, the most radioresistant strain isolated from spices, was $0.24 \mathrm{Mrad}$. These $D_{10}$ values are similar to

Table III. Composition of Molds in Some Selected Spices Isolated from MYG-Chloramphenicol Agar

\begin{tabular}{|c|c|c|c|c|}
\hline Spice & Treatment & Molds count (g) & Mycoflora & $\begin{array}{l}\text { Relative } \\
\text { frequency } \\
\quad(\%)\end{array}$ \\
\hline Black pepper & $\begin{array}{l}\text { Before } \\
\text { storage }\end{array}$ & $1 \times 10^{3}$ & $\begin{array}{l}\text { A. flavus var. columnaris } \\
\text { A. wentii group } \\
\text { A. fumigatus }\end{array}$ & $\begin{array}{l}56 \\
14 \\
31\end{array}$ \\
\hline White pepper & $\begin{array}{l}\text { Before } \\
\text { storage }\end{array}$ & $8 \times 10^{2}$ & $\begin{array}{l}\text { A. flavus var. columnaris } \\
\text { A. fumigatus } \\
\text { Penicillium } \mathrm{sp} .\end{array}$ & $\begin{array}{r}19 \\
75 \\
6\end{array}$ \\
\hline Turmeric & $\begin{array}{l}\text { Before } \\
\text { storage }\end{array}$ & $2 \times 10^{4}$ & $\begin{array}{l}\text { A. chevarieri } \\
\text { A. ruber } \\
\text { A. flavo-furcatis } \\
\text { A. ochraceus group }\end{array}$ & $\begin{array}{c}66 \\
32 \\
1 \\
0.3\end{array}$ \\
\hline Rosemary & $\begin{array}{l}\text { Before } \\
\text { storage }\end{array}$ & $8 \times 10^{3}$ & $\begin{array}{l}\text { A. chevarieri } \\
\text { Penicillium sp. }\end{array}$ & $\begin{array}{r}98 \\
2\end{array}$ \\
\hline Thyme & $\begin{array}{l}\text { Long } \\
\text { storage }\end{array}$ & $8 \times 10^{6}$ & A. chevarieri & 96 \\
\hline
\end{tabular}




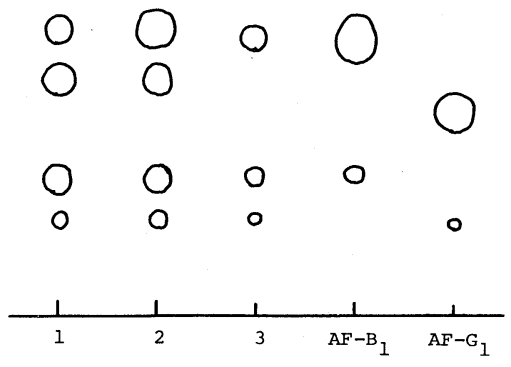

Fig. 1. Blue Fluorescent Spots of Extracts from $A$. flavus var. columnaris Isolated from Spices on Thin Layer Chromatography.

1, S46, 2, S74, 3, A. flavus IFO-30180.

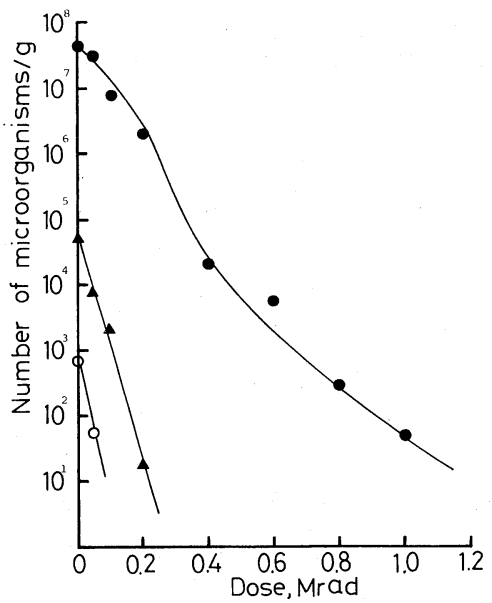

FIG. 2. Inactivation Curves for Microorganisms in Powdered Turmeric A after Gamma-radiation.

- total bacteria; $\bigcirc$, coliforms; $\boldsymbol{\Delta}$, molds.

those in the previous report for retainer type Kamaboko. ${ }^{14)}$ Figure 5 shows the survival patterns of two strains in dried spices with different water activities. B. pumilus $\mathrm{S} 4$ and $B$. megaterium $\mathrm{S} 31$ showed similar $D_{10}$ values in spices with higher water activity ( $a w$, $0.90 \sim 0.98)$ to as in the aerobic phosphate buffer. In contrast, when these organisms were irradiated in the spices with lower water activity (aw, 0.60), the survival curves tended to tail off at higher doses. This effect is similar to that seen in some inactivation curves for microorganisms in gamma-irradiated spices.

\section{Storage effect on irradiated spices}

Many kinds of spices are hygroscopic in

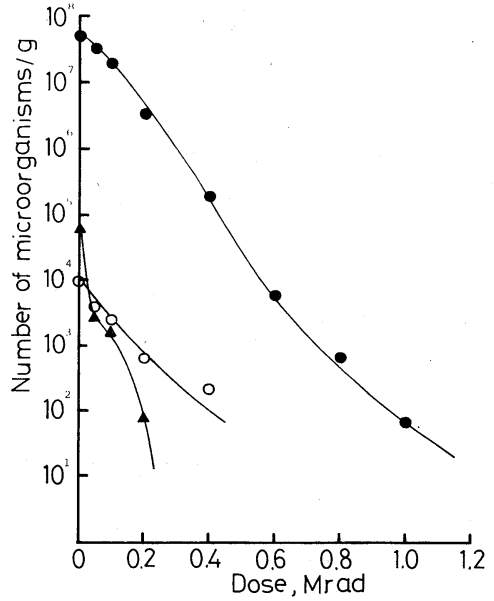

Fig. 3. Inactivation Curves for Microorganisms in Powdered Black Pepper A after Gamma-radiation.

O, total bacteria; $\bigcirc$, coliforms; $\boldsymbol{\Delta}$, molds.

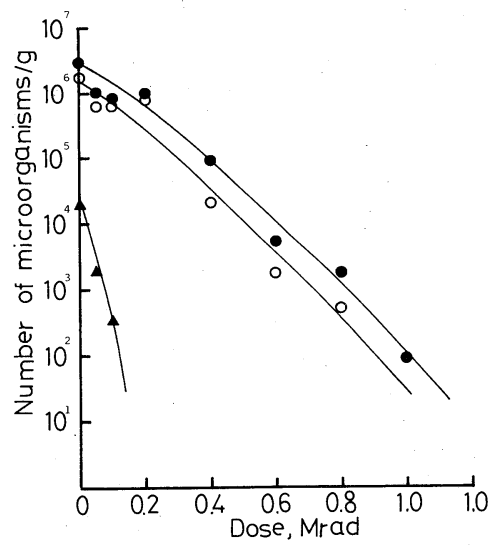

FIG. 4. Inactivation Curves for Microorganisms in Whole White Pepper B after Gamma-radiation.

, total bacteria; $\bigcirc$, coliforms; $\boldsymbol{\Delta}$, molds.

nature, which may encourage putrefaction by molds and cause quality changes of the products. For the storage study, black pepper, white pepper, turmeric and rosemary were used in powder and whole forms.

As shown in Fig. 6, mold growth occurred rapidly in powdered black pepper during the first month of storage and reached more than $10^{6}$ per gram at $35^{\circ} \mathrm{C}$ and $93 \%$ R.H. In this case, the aerial gas volume in the polyethylene pouch decreased considerably and the shape of the pouch changed to as if it had been packed 

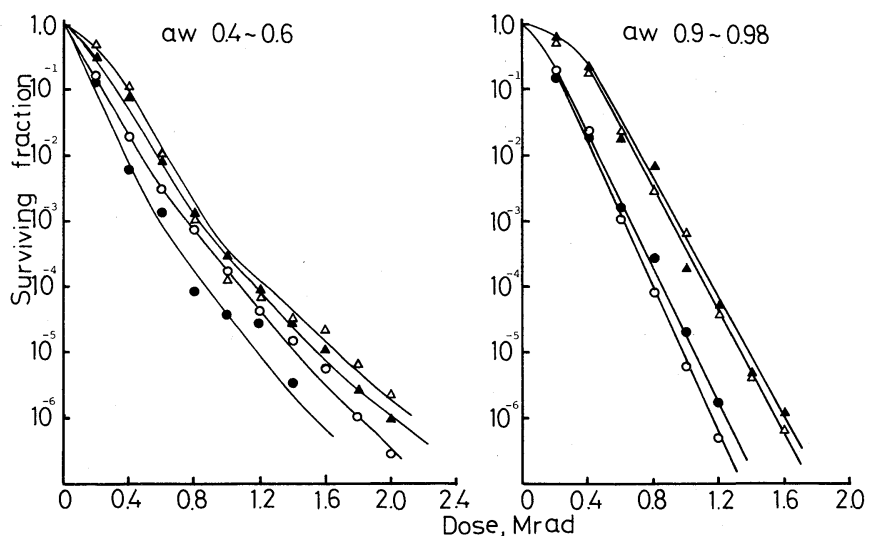

FIG. 5. The Effect of Water Activity of Spices $(a w)$ on the Radiation Sensitivity of B. pumilus S4 and $B$. megaterium S31.

$\bigcirc$, B. pumilus in powdered black pepper; $\bigcirc$, Bumilus in powdered turmeric; $\triangle, B$. megaterium in powdered black pepper; $\boldsymbol{\Lambda}, B$. megaterium in powdered turmeric.

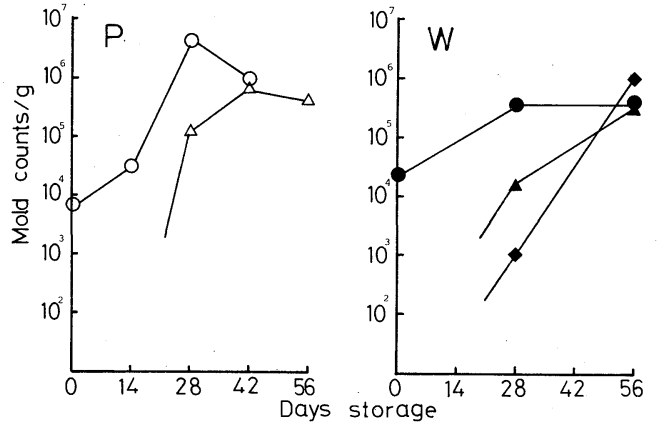

Fig. 6. Effect of Irradiation on the Growth of Osmophilic Molds in Powdered and Whole Black Pepper during Storage at $35^{\circ} \mathrm{C}$ and $90 \sim 93 \%$ R.H.

$\mathrm{P}$, powder; W, whole. $\bigcirc \bigcirc$, non-irrad.; $\triangle \boldsymbol{\Delta}, 0.2 \mathrm{Mrad}$; $\checkmark, 4$ Mrad.

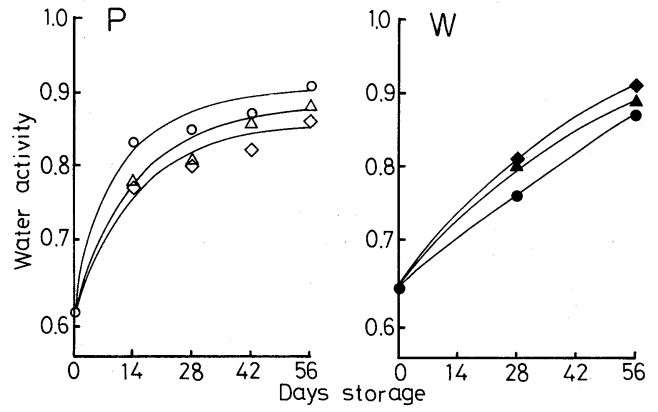

FIG. 7. Effect of Irradiation on the Increase in Water Activity of Powdered and Whole Black Pepper during Storage at $35^{\circ} \mathrm{C}$ and $90 \sim 93 \%$ R.H.

P, powder; W, whole. $\bigcirc$, non-irrad.; $\triangle \boldsymbol{\Delta}, 0.2 \mathrm{Mrad}$; $\diamond \diamond, 0.4$ Mrad. under vaccum. When the aerial gas volume in the pouches of the stored samples decreased, color changes of the spices were observed with the naked eye. A delay in growth of molds was observed in irradiated samples with a dose of $0.2 \mathrm{Mrad}$. When powdered black pepper was irradiated with a dose of $0.4 \mathrm{Mrad}$, mold growth was not observed for more than 2 months of storage. In contrast to the powder form, the absorbed dose of 0.2 to $0.4 \mathrm{Mrad}$ used for the whole black pepper was insufficient to suppress mold growth during storage. This different effect can be explained by that in powder samples, irradiation reduced the rate of increase in $a w$, as shown in Fig. 7, which therefore inhibited the rapid increase of molds. On the contrary, the increase of molds in whole-form samples was independent of the dose but related instead to the increase in aw. In this case, samples irradiated at $0.4 \mathrm{Mrad}$ showed the highest rate of increase in $a w$.

Mold growth was also observed in turmeric (powder), rosemary (powder and whole) and white pepper (powder and whole) during 2 months of storage, and reached $10^{4} \sim 10^{6}$ per gram. However, absorbed doses of 0.2 or 0.4 Mrad were sufficient to suppress the mold growth. A similar relationship of $a w$ and mold growth was also observed for the other kinds of spices, except for a few samples, such as 
Table IV. The Relationship between the Increase in Osmophilic Molds and Water Activity of Representative Spices in Powder form after 4 Months OF StORAGE AT $35^{\circ} \mathrm{C}$ AND $90 \sim 93 \%$ R.H.

\begin{tabular}{|c|c|c|c|c|c|}
\hline \multirow{2}{*}{ Spice } & \multirow{2}{*}{$\begin{array}{l}\text { Dose } \\
\text { (Mrad) }\end{array}$} & \multicolumn{2}{|c|}{ Before storage } & \multicolumn{2}{|c|}{ After 4 months of storage } \\
\hline & & Molds count (g) & $a w$ & Molds count (g) & $a w$ \\
\hline \multirow[t]{2}{*}{ Black pepper } & 0 & $6 \times 10^{3}$ & 0.62 & $4 \times 10^{6}$ & 0.85 \\
\hline & 0.2 & - & 0.62 & $7 \times 10^{5}$ & 0.81 \\
\hline \multirow{2}{*}{ White pepper } & 0 & - & 0.65 & $3 \times 10^{5}$ & 0.83 \\
\hline & 0.2 & - & 0.65 & - & 0.82 \\
\hline \multirow{2}{*}{ Turmeric } & 0 & $1 \times 10^{2}$ & 0.61 & $3 \times 10^{5}$ & 0.83 \\
\hline & 0.2 & - & 0.61 & - & 0.77 \\
\hline \multirow[t]{2}{*}{ Rosemary } & 0 & $3 \times 10^{1}$ & 0.56 & $1 \times 10^{5}$ & 0.79 \\
\hline & 0.2 & - & 0.56 & - & 0.79 \\
\hline \multirow[t]{2}{*}{ Bay leaves } & 0 & $1 \times 10^{3}$ & 0.55 & $4 \times 10^{4}$ & 0.76 \\
\hline & 0.2 & - & 0.55 & - & 0.70 \\
\hline \multirow{2}{*}{ Bacil } & 0 & $3 \times 10^{2}$ & 0.52 & $2 \times 10^{4}$ & 0.80 \\
\hline & 0.2 & - & 0.52 & - & 0.76 \\
\hline \multirow{2}{*}{ Thyme } & 0 & $3 \times 10^{1}$ & 0.54 & $1 \times 10^{4}$ & 0.73 \\
\hline & 0.2 & - & 0.54 & - & 0.73 \\
\hline \multirow[t]{2}{*}{ Paprika } & 0 & - & 0.50 & - & 0.73 \\
\hline & 0.2 & - & 0.50 & - & 0.70 \\
\hline \multirow[t]{2}{*}{ Garlic } & 0 & - & 0.44 & - & 0.65 \\
\hline & 0.2 & - & 0.44 & - & 0.68 \\
\hline \multirow{2}{*}{ Fish meal } & 0 & $3 \times 10^{2}$ & 0.66 & - & 0.73 \\
\hline & 0.2 & - & 0.66 & - & 0.73 \\
\hline
\end{tabular}

-, below the detectable limit.

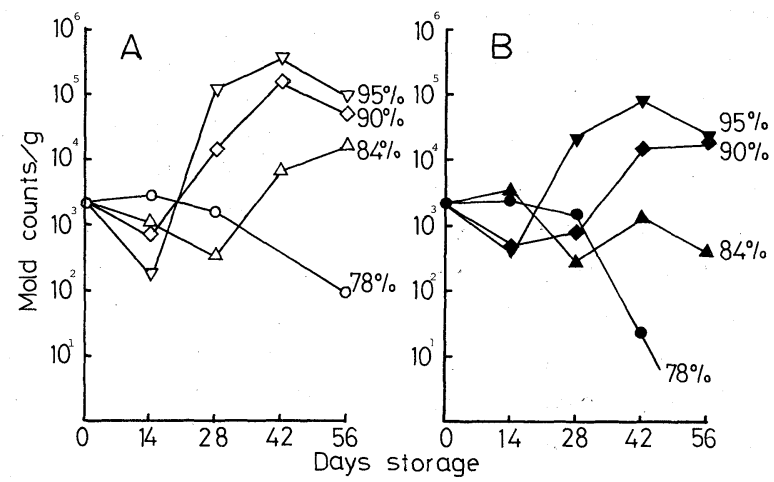

FIG. 8. Effect of Different Relative Humidity Levels during Storage on the Growth of Osmophilic Molds in Powdered Black Pepper Stored in Polyethylene Pouches of Different Thickness.

A, $73 \mu \mathrm{m}$ thickness; B, $99 \mu \mathrm{m}$ thickness.

powdered paprika and garlic, in which no mold growth was observed as in the case of fish meal (Table IV). Even so, the aw of all kinds of spices increased rapidly compared with the fish meal.

The effect of different relative humidity levels on the growth of molds in powdered black pepper was also investigated. Figure 8 shows that a relative humidity of over $84 \%$ allowed growth of molds regardless of the thickness of the polyethylene pouch. However, the growth rate was $73 \mu \mathrm{m}$ thickness polyethylene was higher than with $99 \mu \mathrm{m}$ material after 42 days of storage. A similar relationship of mold 
growth and relative humidity was observed under the storage condition of $30^{\circ} \mathrm{C}$.

In these studies, only the Aspergillus glaucus and $A$. restrictus groups propagated in spices, and the $A$. flavus group and other toxigenic molds tended to disappear during storage.

\section{DISCUSSION}

Spice consumption in Japan is increasing with the steady growth of the food industry, and approximately 30 thousand tons is consumed per year. ${ }^{4)}$ About $85 \%$ of spices are used in the food industry and $15 \%$ in the household sector. In Japan, nearly all spices are imported from overseas countries, and their contamination by microorganisms has been causing serious problems in food processing. Several methods have been tried for microorganism-decontamination of spices such as fumigation with ethylene oxide or steam treatment. Recently, super-heated steam treatment was also applied to some kinds of spices. $^{15,16)}$ However, many spices always show losses to some degree of volatile oils and other important constituents. Radiation treatment has been found to be the most promising method for this purpose. In the study of Goto et al., ${ }^{6}$ the main contaminants of 11 kinds of spices consisted of Bacillus subtilis and $B$. licheniformis, and many contaminants were destroyed by irradiation with $0.5 \mathrm{Mrad}$. In our study, B. subtilis and B. pumilus were the common contaminants in many spices, and an irradiation dose of $1.0 \mathrm{Mrad}$ appeared to be sufficient for decreasing spore-forming bacteria to below $10^{3}$ per gram, the Japanese hygenic standard. However, inactivation curves for microorganisms in irradiated spices tended to tail off at higher doses, and this effect can be explained as due to the increasing radiation-resistivity of spore-forming bacteria at lower water activity or residual radiation-resistant microorganisms such as B. megaterium in spices.

In this study, mold growth was observed in many kinds of spices during the summer condition of high humidity in polyethylene pouches. These results shows the possibility of mold propagation in spices under unfavorable conditions of storage and shipment, especially in tropical countries. The damage to spices caused by microorganisms should be considerable in Japan because the summer humidity and temperature are high enough for the growth of molds or bacteria. Irradiation can suppress the growth of molds in spices packed in polyethylene bags during storage and transportation with a dose of $0.4 \sim 0.6$ Mrad. In this study, an amount of the Aspergillus flavus group was isolated from many kinds of spices. However, these toxigenic molds disappeared and the mycoflora became dominated by the $A$. glaucus and $A$. restrictus groups during storage under summer conditions. Further studies on the growth of $A$. flavus and other toxigenic molds during storage are required.

Acknowledgments. The authors wish to thank Drs. I. Ishigaki and T. Kume for their helpful discussions during the course of this investigation.

\section{REFERENCES}

1) A. H. Schwab, A. D. Harpestad, A. Swartzentruber, J. M. Lanier, B. A. Wentz, A. P. Duran, R. J. Barnard and R. B. Read, Jr., Appl. Environ. Microbiol., 44, 627 (1982).

2) R. Baxter and W. H. Holzapfel, J. Food Sci., 47, 570 (1982).

3) M. Vajdi and N. M. Pereira, J. Food Sci., 38, 898 (1973).

4) K. Kawashima, Nippon Shokuhin Kogyo Gakkaishi, 28, 52 (1981).

5) H. M. Gottschalk, Food Irradiation Information, No. 7,7 (1977).

6) A. Goto, K. Yamazaki and M. Oka, Food Irradiation, Japan, 6, 35 (1971).

7) M. I. Eiss, Food Tech., Australia, 36, 362 (1984).

8) Regulations for Using Ionizing Radiation for Treating Food Proposed by the Food and Drug Administration of the United States of America, Food Irradiation Newsletter, 8, 20 (1984).

9) S. Bagiawati, H. Watanabe and N. Tamura, Food irradiation, Japan, 20, 23 (1985).

10) H. Ito, A. Begum, T. Kume and M. Takehisa, Nippon Nôgeikagaku Kaishi, 57, 9 (1983).

11) R. E. Buchanan and N. E. Gibbons (eds.), "Bergey's Manual of Determinative Bacteriology," 8th Ed., Williams and Wilkins, Baltimore, 1974. 
12) K. B. Raper and D. I. Fennell, "The Genus Aspergillus," Williams and Wilkins, Baltimore, 1965.

13) M. Hara, H. Murakami, H. Kasama, D. I. Fennel and C. W. Hesseltine, Jozo Shikenjo Hokoku, 145, 1 (1973).

14) H. Ito and H. Iizuka, Nippon Shokuhin Kogyo
Gakkaishi, 25, 14 (1978).

15) T. Yoshida and T. Hyodo, Food Engineering, 38, 86 (41966)

16) N. Tsukada, "Advances in Food Science and Technology," Nippon Shokuhin Kogyo Gakkai, 1983, p. 71. 